

\title{
Value Accrual to Customers, Installers, and Financiers in Third-Party Owned Solar PV Markets
}

David A. Bielen, Eric O'Shaughnessy, Benjamin Sigrin, and Robert Margolis

National Renewable Energy Laboratory

NREL is a national laboratory of the U.S. Department of Energy

Office of Energy Efficiency \& Renewable Energy

Operated by the Alliance for Sustainable Energy, LLC

This report is available at no cost from the National Renewable Energy Laboratory (NREL) at www.nrel.gov/publications.

\section{Technical Report}

NREL/TP-6A20-70552

February 2019 


\title{
GNREL
}

\section{Value Accrual to Customers, Installers, and Financiers in Third-Party Owned Solar PV Markets}

\author{
David A. Bielen, Eric O'Shaughnessy, Benjamin Sigrin, \\ and Robert Margolis
}

National Renewable Energy Laboratory

\section{Suggested Citation}

Bielen, David A., Eric O'Shaughnessy, Benjamin Sigrin, and Robert Margolis. 2019.

Value Accrual to Customers, Installers, and Financiers in Third-Party Owned Solar PV Markets. Golden, CO: National Renewable Energy Laboratory. NREL/TP-6A20-70552.

https://www.nrel.gov/docs/fy19osti/70552.pdf.

NREL is a national laboratory of the U.S. Department of Energy Office of Energy Efficiency \& Renewable Energy Operated by the Alliance for Sustainable Energy, LLC

This report is available at no cost from the National Renewable Energy Laboratory (NREL) at www.nrel.gov/publications.

Contract No. DE-AC36-08GO28308
Technical Report NREL/TP-6A20-70552

February 2019

National Renewable Energy Laboratory 15013 Denver West Parkway Golden, CO 80401 303-275-3000 • www.nrel.gov 


\section{NOTICE}

This work was authored by the National Renewable Energy Laboratory, operated by Alliance for Sustainable Energy, LLC, for the U.S. Department of Energy (DOE) under Contract No. DE-AC36-08GO28308. Funding provided by U.S. Department of Energy Office of Energy Efficiency and Renewable Energy Solar Energy Technologies Office. The views expressed in the article do not necessarily represent the views of the DOE or the U.S. Government.

This report is available at no cost from the National Renewable Energy Laboratory (NREL) at www.nrel.gov/publications.

U.S. Department of Energy (DOE) reports produced after 1991 and a growing number of pre-1991 documents are available free via www.OSTI.gov.

Cover Photos by Dennis Schroeder: (clockwise, left to right) NREL 51934, NREL 45897, NREL 42160, NREL 45891, NREL 48097, NREL 46526.

NREL prints on paper that contains recycled content. 


\section{Acknowledgments}

This work was supported by the Solar Energy Technologies Office at the U.S. Department of Energy. The authors would like to thank the following individuals and organizations for their thoughtful review of this work: Kenneth Gillingham (Yale University), Jacquelyn Pless (University of Oxford), Kelsey Horowitz (NREL), Daniel Steinberg (NREL), and Ammar Qusaibaty (DOE). The authors would also like to thank Mike Meshek (NREL) and Jarett Zuboy (consultant) for editorial support. 


$\begin{array}{ll}\text { List of Acronyms and Abbreviations } \\ \text { \$/W } & \text { dollar per watt } \\ \text { BNEF } & \text { Bloomberg New Energy Finance } \\ \text { DC } & \text { direct current } \\ \text { HHI } & \text { Herfindahl-Hirschman Index } \\ \text { IRR } & \text { internal rate of return } \\ \text { ITC } & \text { investment tax credit } \\ \text { IV } & \text { instrumental variables } \\ \text { kWh } & \text { kilowatt-hour } \\ \text { MACRS } & \text { Modified Accelerated Cost Recovery System } \\ \text { NPV } & \text { net present value } \\ \text { OLS } & \text { ordinary least-squares } \\ \text { PPA } & \text { power purchase agreement } \\ \text { PTC } & \text { PVUSA Test Conditions } \\ \text { PV } & \text { solar photovoltaic(s) } \\ \text { Q } & \text { quarter } \\ \text { SEIA } & \text { Solar Energy Industries Association } \\ \text { TPO } & \text { third-party owned } \\ \text { TTS } & \text { Tracking the Sun }\end{array}$

iv 


\section{Executive Summary}

Residential solar photovoltaic (PV) adopters can save money by using PV output to reduce utility electric bills. Most PV adopters are also eligible for various financial incentives such as up-front rebates that reduce the cost of adoption. Prospective customers with higher potential bill savings and rebates should be willing to pay more for PV than customers with lower potential bill savings and rebates, all else equal. PV installation companies may use this knowledge to "capture" some of these values by offering higher prices to customers with higher potential bill savings and rebates, allowing installers to increase their margins. Alternatively, installers may "pass through" these values to customers in order to acquire more customers and increase market share. The extent to which these values are captured or passed through could have important implications for PV markets, the PV installation industry, and PV deployment.

We study value pass-through in the context of third-party ownership (TPO): a model where a PV installation company installs a system owned by a third party with system output benefits accruing to the system host. To conduct our analysis, we use a unique data set with over 16,000 records of residential PV TPO sales transactions spanning 2012-2015 made on a customer finance platform. The data set includes systems with different contract structures: specifically, monthly payments over the course of a (typically) 20-year contract (i.e., power purchase agreements (PPAs) or leases) versus fully prepaid. While prior PV pricing studies have employed system-level data, studies of the TPO market have been limited to separate analyses of system price (the price paid by the system owner to the installer) and customer payments (the payments made by the customer to the system owner). In contrast, our access to sales records allows us to observe a broader set of transactions and prices. Notably, these include the cost financiers paid to the system installer, the contract price offered to the consumer, the consumer's expected avoided utility electricity costs at the time of adoption, and the monetary value of any state and local rebates. These data allow us to estimate the extent to which the values of these incentives are shared between financier, system installer, and consumer.

We find evidence that PV financiers and installers capture much of the value of electricity bill savings while passing rebates through to adopters. We find that the level of pass-through varies by contract type: installation companies capture more value through PPAs than for prepaid contracts. We find some evidence that pass-through rates to customer payments for PPAs change with degree to which market shares are skewed toward high-volume installers, known as market concentration. Though we generally don't observe particularly strong associations, we find installers are able to capture more of the value of bill savings in more concentrated markets, suggesting that increased levels of competition (i.e., customers receiving more quotes from more installers) may curb the ability of installers to capture this value stream.

The results of our analysis yield two implications. First, the financial benefits of bill savings and upfront rebates accrue to installers and customers in different ways in TPO markets. Our results indicate that the value of bill savings mostly accrue to installers in the form of higher margins, while the value of rebates largely accrue to customers in the form of lower prices. Second, we find evidence that more competitive markets - meaning markets where customers receive more quotes from more installerscurb the ability of installers to capture the value of bill savings and possibly force installers to pass the value of rebates through to customers. This result suggests that competitive PV markets result in higher levels of value accrual to end-use customers and possibly in higher PV deployment. 


\section{Table of Contents}

Executive Summary ........................................................................................................................... iii





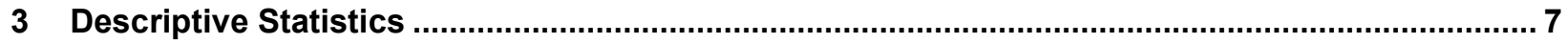



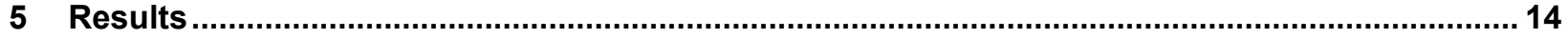









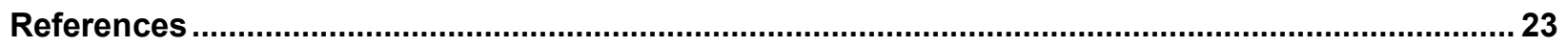








\section{List of Figures}



Figure 2. Schematic depiction of interactions in TPO PV procurement .................................................... 2

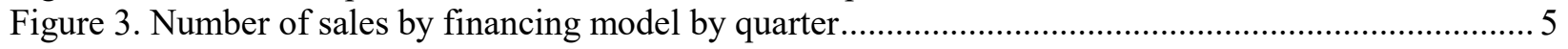

Figure 4. Number of sales by financing model by state ..................................................................... 6

Figure 5. IRR distributions for all PPAs (left) and prepaid contracts (right) ........................................ 10

Figure 6. Distributions of expected gross utility bill savings (top) and state and local rebates (bottom) by state and contract type

Figure 7. Symbols used to represent capture, pass-through, and pass-through over-shift ....................... 14

Figure 8. Results from base model specification ............................................................................ 15

Figure 9. Financial Incentive pass-through decomposition by contract type......................................... 17

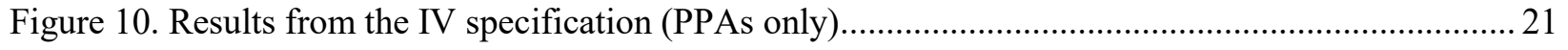

\section{List of Tables}

Table 1. Summary Statistics by Contract Type ................................................................................ 8

Table 2. Results from Model Specification with Market Concentration ................................................ 19

Table B-1. Results from Base Model Specification.......................................................................... 27

Table B-2. Financial Incentive Pass-Through Decomposition by Contract Type .................................. 28

Table B-3. Results from the IV Specification (PPAs only) ..................................................................... 29 


\section{Introduction}

The rapid growth of the U.S. residential solar photovoltaic (PV) market has been enabled in large part by the ability of customers to capture the value of financial incentives associated with PV systems, including electricity bill savings and rebates provided by federal, state, and local governments. The extent to which customers benefit from these values depends on the relationship between PV value and PV prices. PV installers can "capture" value by offering higher prices to prospective customers who have more to gain from PV adoption. Alternatively, PV installers can "pass through" value by offering prices that are independent of value, or possibly by offering lower prices for systems with higher value. Similarly, PV financiers can capture or pass-through value (Figure 1).



Figure 1. Value pass-through and capture in PV markets

Value pass-through has been studied primarily in the context of customer-owned PV systems (Dong, Wiser, and Rai 2014; Gillingham et al. 2016; Nemet et al. 2016), though some recent attention has been paid to third-party owned (TPO) systems (Pless and van Benthem 2017). In the TPO model, an installer sells a customer-sited PV system to a third-party financier, who then sells the power produced by the system to the customer. Given the importance of TPO systems in spurring market growth, understanding how bill savings and rebates are passed through to system prices and contracted power prices is helpful in understanding the structure of the market and determining what, if any, policy interventions may be required to promote an efficient and equitable market.

In this report, we use a unique data set of more than 16,000 TPO transactions (prepaid contracts, power purchase agreements, and leases) from 2012 to 2015 to study value pass-through. The data set, provided by a customer finance firm, allows us to analyze transactions between the installer and the customer, between the customer and the financier, and - for the first time-between the installer and the financier (Figure 2). By analyzing all three transactions, we can provide insights 
into how bill savings and rebates are captured by or passed between the financier, installer, and customer.



Figure 2. Schematic depiction of interactions in TPO PV procurement

Our report contributes to a small literature on empirical studies of price discrimination. ${ }^{1}$ Because installers and financiers typically know how much money customers will save on their utility bills, they have a signal for how much customers might value a PV installation. In general, service industries such as PV installation meet the basic criteria that allow for price discrimination (Lambrecht et al. 2012). In some service industries, including PV, customers procure services through competitive bids. Strategic bidding (auction) theory suggests that pricing according to the customer's valuation is the theoretically optimal pricing practice in competitive bidding processes. According to strategic bidding theory, competitive bidders view the bids of their rivals as draws from a probability distribution (Riley and Samuelson 1981; McAfee and McMillan 1987; Milgrom 1989; Rothkopf and Harstad 1994; Lorentziadis 2016). Under monopoly conditions, bidders can theoretically exercise perfect price discrimination and completely extract consumer surplus. As the number of bidders increases, bid prices decrease toward the service's cost.

This type of price discrimination is referred to in the management literature as value-based pricing. According to this literature, firms may use cost-, competition-, or value-based strategies to set prices within a price-discretion range (Kortge and Okonkwo 1993; Ingenbleek et al. 2003; Hinterhuber 2008b), with value-based pricing broadly recognized as the optimal profitmaximization strategy (Cannon and Morgan 1990; Monroe 2002; Ingenbleek et al. 2003; Hinterhuber 2008b). Value-based pricing is particularly effective for differentiated products in less competitive markets and for new products (Ingenbleek et al. 2003). Nonetheless, firms tend to use competition- and cost-based pricing in practice (Abratt and Pitt 1985; Kortge and Okonkwo 1993; Indounas 2006; Hinterhuber 2008a). Hinterhuber (2008a) finds that about 44\% of companies use competition-based pricing and about $37 \%$ use cost-based pricing, compared

\footnotetext{
${ }^{1}$ Much of the recent work in this literature focuses on big data applications and internet purchases. For example, Shiller (2016) examines personalized pricing schemes for Netflix, finding that using all customer web-browsing data to set prices increases profits by far more than using demographics alone. For an overview of recent contributions in this area, see Merler (2017).
} 
with $17 \%$ that use value-based pricing. The author posits that firms avoid value-based pricing owing to challenges associated with assessing value, communicating value, segmenting markets, and training sales staff to use value-based pricing.

Our report also contributes to the literature on the empirical estimation of tax and subsidy passthrough, particularly for the PV market. ${ }^{2}$ Because most U.S. residential PV has received at least some financial incentives, pass-through of incentives to the consumer in the form of reduced prices is important for understanding the efficacy of public expenditures and the strategies of PV installers and financiers. Dong, Wiser, and Rai (2014) find that installers passed through nearly all the value of rebates offered by the State of California to consumers in the form of lower prices, though only host-owned systems were considered. In the study most similar to ours, Pless and van Benthem (2017) find similar results for host-owned systems, but they find that TPO systems passed through greater than $100 \%$ of the financial value of rebates. The authors conclude that such high pass-through rates are an outcome of imperfectly competitive PV markets and a convex demand curve. Our study's unique contributions to this literature include estimating TPO PV value pass-through for both installers and financiers and distinguishing passthrough rates by TPO financing type (monthly payment vs. fully prepaid arrangements).

It is important to note that both pass-through and capture can be rational installer strategies. Installers that pass values through to their customers may do so in order to acquire more customers and increase market share. Installers that capture these values may do so in order to increase profit margins. From a policy perspective, the desirability of pass-through or capture depends on a variety of factors such as local market context. Increased pass-through may be desirable if high rates of capture are stymying adoption rates and reducing PV deployment. Alternatively, increased capture may be desirable if low margins are preventing the formation of a local PV installation industry.

The remainder of the report is structured as follows. Section 2 describes our data sources and the TPO procurement process. Section 3 presents descriptive statistics for our data set. Section 4 describes our pass-through estimation approach. Section 5 presents and discusses the results, and Section 6 offers conclusions.

\footnotetext{
${ }^{2}$ See Pless and van Benthem (2017) for a discussion of the broader empirical literature on pass-through outside of the PV industry.
} 


\section{Data}

The data underlying this analysis represent transactions on a customer finance platform, henceforward referred to as simply the platform. Over the period of our study, the platform essentially functioned as a market-maker between PV installers and financiers, allowing installers without the necessary means or desire to offer TPO systems and financing to prospective customers to obtain financing. ${ }^{3}$ Figure 2 (Section 1) illustrates how TPO PV procurement occurs in the absence of vertical integration. Installers identify customers who are interested in hosting a PV system. After a consultation with a customer, an installer designs a system and quotes a system price to a financier. Based on the system price quote and other information (e.g., local market conditions, the customer's credit score), the financier offers a financial package to the customer that specifies the payments the customer must make to access the system's power output. With the platform, this quote is relayed to the customer by the installer, meaning that the financier-customer interaction is strictly virtual.

Customers in the data set received financing quotes for up to three TPO contract types: power purchase agreements (PPAs), leases, and prepaid contracts. Under PPAs, customers make monthly payments for the power that the system produces on a per-kilowatt-hour (kWh) basis. Leases also involve monthly payments, but customers pay a flat rate regardless of system production. ${ }^{4}$ Under both arrangements, customers assume either no upfront cost, or an amount that is typically small relative to the total expected payments over the life of the contract. Lease agreements make up a small fraction of our final data set; thus, we group PPA and lease arrangements together and refer to them jointly as PPAs. For a discussion of how contract pricing might differ between PPAs and leases, see Davidson and Steinberg (2013). In contrast, under prepaid contracts, customers make a lump sum payment up front for all system production over the life of the contract. Like host ownership, prepaid contracts require a large initial capital outlay, but they allow the value of tax incentives - most notably the federal investment tax credit (ITC) and accelerated depreciation — to be capitalized directly into the price the customer pays. ${ }^{5}$

Including both PPAs and prepaid contracts, the raw data set consists of 20,041 accepted quotes for TPO systems from early 2012 to the end of $2015 .{ }^{6}$ Consistent with previous studies (Gillingham et al. 2016; Nemet et al. 2016), we clean the data by dropping observations for which the installer's price quote was below $\$ 1 / \mathrm{W}$ or above $\$ 20 / \mathrm{W}$ as probable data-entry errors, because these values bound market prices over our sample period (Barbose and Darghouth 2017). We also drop any observations for which system price and value streams resulted in gross customer savings below $\$ 0.05 / \mathrm{kWh}$ or above $\$ 0.50 / \mathrm{kWh}$ as probable data-entry errors, because it is unlikely a customer's marginal cost of electricity would be outside these bounds for retail rates in the states examined (NREL 2017). To focus our study on residential customers, we drop observations with system sizes larger than $10 \mathrm{~kW}$, reducing our sample to 17,413 observations.

\footnotetext{
${ }^{3}$ Since the period of our study, the platform has shifted its role in the residential PV market toward providing financing directly.

${ }^{4}$ Lease contracts often include clauses that compensate customers if system production does not meet a certain level. However, our data set does not specify whether such clauses were used.

${ }^{5}$ The capitalization of the ITC and depreciation into customer prices applies to any TPO arrangement.

${ }^{6}$ Data for non-accepted quotes were also available; however, this analysis focuses on accepted quotes to avoid dataquality issues that might be more prevalent in the subsample of non-accepted quotes. Data-quality assurance and analysis of the full set of quotes will be a focus of future work. Additionally, 34 accepted quotes using solar loans were dropped to focus the study on TPO products.
} 
Finally, we exclude observations from installers that focus on low-income clients, from installers that accounted for fewer than 10 installations, from financiers that accounted for fewer than 20 installations, and in counties for which installer concentration measures could not be calculated. After cleaning the data, our final data set consists of 16,078 observations.

Breakdowns of our observations over time and across states are illustrated in Figure 3 and Figure 4. PPAs compose about $80 \%$ of the data set and are the most prevalent financing model in each quarter over the entire period. Prepaid contracts become less prevalent over time, falling from a peak of $45 \%$ of quotes in the first quarter (Q1) of 2013 to just 3\% of quotes in Q4 2015. The distribution of PV system sales over time in our data set is not representative of overall market activity. For example, while sales in our data set declined in 2015, market-wide sales increased in the same period. Though conclusions reached using our data may not represent all market participants, the volume of sales over the period studied is substantial enough to suggest broader trends in this market. Still, as a robustness check, we applied our empirical model (described in Section 4) to the subset of the data that excludes 2015, and our results did not differ materially.



Figure 3. Number of sales by financing model by quarter

The data include quotes from seven states. California accounts for $91 \%$ of the quotes and thus disproportionately contributes to analytical results. The prevalence of different financing models varies by state according to market conditions. Though all states except Arizona have prepaid contracts, they only make up a significant portion of the total in California, Massachusetts, and New Jersey. 




Figure 4. Number of sales by financing model by state

The platform data include price information, estimated customer bill savings, rebate value (if applicable), system variables, customer geographic information, temporal variables, and installer and financier identifiers. The price information includes system prices paid by financiers to installers and contract terms between customers and financiers. System variables include characteristics such as system size, module brand and model, and inverter brand and model. Temporal variables include, for example, quote dates, quote acceptance dates, and installation dates. We use the quote acceptance date to reflect the timing of pricing decisions, because this variable is more reliable than the quote date. ${ }^{7}$

The level of detail in the platform data set enables us to merge it with several variables from other data sets. Using customer geographic information, we map observations to county-level measures of installer concentration calculated using Lawrence Berkeley National Laboratory's Tracking the Sun (TTS) data set (Barbose and Darghouth 2017). The TTS data set captures 85\% of U.S. residential PV installations, includes information on installation dates and locations as well as installer identities, and indicates whether installations are TPO. The platform geographic data also allow us to match observations to tract-level demographic characteristics extracted from S\&P Global's Market Intelligence Platform. Finally, the temporal variables and system characteristics enable us to include information on module and inverter price levels, obtained from Bloomberg New Energy Finance (BNEF) and the Solar Energy Industries Association (SEIA)/GTM Research, respectively (BNEF 2016; SEIA/GTM Research 2013, 2014, 2015, 2016).

\footnotetext{
${ }^{7}$ For some observations in our data set, the quote date appears to reflect when the installer entered the quote into the platform software, rather than when the quote was presented to the customer. This leads to counterintuitive observations in which the system installation date precedes the quote date. The quote acceptance date, in contrast, follows a more logical timeline vis-à-vis the other temporal variables.
} 


\section{Descriptive Statistics}

In this section, we introduce the variables used in our empirical analysis (described in Section 4) and present descriptive statistics associated with our final data set, drawing attention to key differences between PPAs and prepaid contracts. We also present distributions for financier rates of return for expected utility bill savings and state and local rebates. ${ }^{8}$

Table 1 (next page) describes the variables used in our analysis. All variables reflecting monetary values have been normalized to year 2015 dollars. Those same variables have also been converted to per-watt values $(\$ / \mathrm{W})$ by dividing by system size.

The first set of variables in the table reflects prices. System prices reflect the amount that financiers pay to installers including component prices, labor costs, markups, and so forth. Across PPAs and prepaid contracts, the mean system prices in the data set are similar. Customer payments reflect the amount that customers pay to financiers to host PV systems and use (or receive utility bill credit for) their production. For prepaid contracts, these values are a lump sum payment due at the time of system installation. For PPAs, these values are the discounted sum of expected future payments over the term of the contract, assuming a $7 \%$ discount rate. ${ }^{9}$ The mean customer payment for PPAs is higher than for prepaid contracts, possibly reflecting that financiers expected an IRR higher than $7 \%$ for their investment. ${ }^{10}$

The second set of variables reflects bill savings and rebates. Expected gross savings is defined as the expected savings for customers on their utility bills in the first year after installation, before accounting for the payments they make for PV system production. ${ }^{11}$ There is no substantial difference in means between prepaid contracts and PPAs for this variable. State and local rebates accrue to the financiers who own the systems. ${ }^{12}$ Almost half of prepaid contracts in the data set are associated with a rebate compared with just a quarter of PPAs (as denoted by "rebate indicator" in the table). Descriptive statistics for the rebate levels in the table are calculated for the subset of systems that qualified for a rebate.

The next set of variables reflects contract terms associated primarily with PPAs. Escalator rates specify the percentage by which the PPA price increases annually, with $19 \%$ of PPAs associated with no escalator. The most common escalator value by far is $2.9 \%$ ( $72 \%$ of PPAs). Down payments range from $\$ 250$ to $\$ 5,000$ (nominal). About $87 \%$ of PPA customers made an upfront

\footnotetext{
${ }^{8}$ Note that these rebates do not include the Federal ITC.

${ }^{9}$ To calculate the discounted sum of expected payments, we apply price, quantity, and contract variables found in the data set. Specifically, we multiply the per-kWh price of electricity by the quantity of expected year-one production for each year of the contract, accounting for any price escalators and decrementing system production by $0.5 \%$ annually (Gillingham et al. 2016). Down payments are applied as an initial outlay. The discount rate is also used by Gillingham et al. (2016).

${ }^{10}$ While the minimum value for customer payments for prepaid contracts seems implausibly low, it represents an outlier and omitting that observation from the analysis does not change the results in any significant way. In total, only 16 prepaid observations have customer payments below $\$ 1 / \mathrm{W}$, and most of those are above $\$ 0.66 / \mathrm{W}$.

${ }^{11}$ When discussing our regression results in Section 5.1, we translate expected gross bill savings into a value for the life of the contract under plausible assumptions about the rate of retail electricity price growth.

${ }^{12} \mathrm{We}$ observe the level of state and local rebates for each observation directly in the platform data set, but we do not have any information about the program through which the rebate was provided.
} 
payment. Finally, the data set only includes two contract lengths: 20 and 25 years, with the former much more common (71\% of all PPAs, and all prepaid contracts).

Table 1. Summary Statistics by Contract Type

\begin{tabular}{|c|c|c|c|c|c|c|c|c|}
\hline & \multicolumn{4}{|c|}{ PPA } & \multicolumn{4}{|c|}{ Prepaid Contract } \\
\hline & Mean & Std Dev & Min & $\operatorname{Max}$ & Mean & Std Dev & Min & Max \\
\hline \multicolumn{9}{|l|}{ System and power prices } \\
\hline System price $(2015 \$ / W)$ & 4.42 & 1.03 & 1 & 15.07 & 4.51 & 0.8 & 1.1 & 7.47 \\
\hline $\begin{array}{l}\text { Customer payments } \\
(2015 \$ / W)\end{array}$ & 3.73 & 0.93 & 0.93 & 7.03 & 2.9 & 0.62 & 0.05 & 5.05 \\
\hline \multicolumn{9}{|l|}{ Financial incentives } \\
\hline $\begin{array}{l}\text { Expected gross savings } \\
(2015 \$ / \mathrm{W})\end{array}$ & 0.36 & 0.09 & 0.06 & 0.75 & 0.37 & 0.09 & 0.09 & 0.75 \\
\hline Rebate indicator (\%) & 0.24 & 0.43 & 0 & 1 & 0.45 & 0.5 & 0 & 1 \\
\hline Rebate level $(2015 \$ / \mathrm{W})$ & 0.31 & 0.28 & 0 & 1.71 & 0.2 & 0.07 & 0.12 & 1.45 \\
\hline \multicolumn{9}{|l|}{ Financing terms } \\
\hline Escalator (\%) & 2.3 & 1.2 & 0 & 3.9 & - & - & - & - \\
\hline Down payment $(2015 \$ \mathrm{~W})$ & 0.09 & 0.26 & 0 & 1.89 & - & - & - & - \\
\hline Term (years) & 21.44 & 2.26 & 20 & 25 & 20 & 0 & 20 & 20 \\
\hline \multicolumn{9}{|l|}{ Market concentration } \\
\hline $\mathrm{HHI}$ (all systems) & 0.1 & 0.06 & 0.03 & 0.48 & 0.08 & 0.04 & 0.03 & 0.49 \\
\hline HHI (TPO only) & 0.26 & 0.13 & 0.06 & 1 & 0.18 & 0.12 & 0.07 & 0.83 \\
\hline \multicolumn{9}{|l|}{ System characteristics } \\
\hline System size (kW) & 5.94 & 1.74 & 2 & 10 & 6.15 & 1.83 & 2 & 10 \\
\hline Ground mounting (\%) & 0.01 & 0.09 & 0 & 1 & 0.01 & 0.11 & 0 & 1 \\
\hline Module PTC (watts) & 228 & 9 & 162 & 314 & 231 & 16 & 172 & 314 \\
\hline DC optimized inverter (\%) & 0.04 & 0.19 & 0 & 1 & 0.01 & 0.09 & 0 & 1 \\
\hline Premium module (\%) & 0.08 & 0.27 & 0 & 1 & 0.2 & 0.4 & 0 & 1 \\
\hline \multicolumn{9}{|l|}{ Component price indices } \\
\hline $\begin{array}{l}\text { Module price index } \\
(2015 \$ / \mathrm{W})\end{array}$ & 0.78 & 0.08 & 0.69 & 1.11 & 0.84 & 0.07 & 0.69 & 1.04 \\
\hline $\begin{array}{l}\text { Inverter price index } \\
(2015 \$ / W)\end{array}$ & 0.43 & 0.16 & 0.18 & 0.70 & 0.49 & 0.15 & 0.18 & 0.70 \\
\hline \multicolumn{9}{|l|}{$\begin{array}{l}\text { Demographic } \\
\text { characteristics }\end{array}$} \\
\hline Pop. density (per 100-mi²) & 4,331 & 3,650 & 0.5 & 38,059 & 3,779 & $3,381.2$ & 0.5 & 47,238 \\
\hline $\begin{array}{l}\text { Owner-occupied housing } \\
\text { density (per } 100-\mathrm{mi}^{2} \text { ) }\end{array}$ & 934 & 685 & 0.1 & 5,762 & 859 & 690 & 0.1 & 6,167 \\
\hline $\begin{array}{l}\text { No high school diploma } \\
(\%)\end{array}$ & 14.7 & 10.8 & 0.1 & 72.1 & 12.3 & 9.0 & 0.0 & 57.3 \\
\hline High school graduate (\%) & 55.7 & 10.2 & 12.4 & 78.7 & 54.0 & 12.7 & 13.5 & 77.8 \\
\hline $\begin{array}{l}\text { Bachelor's degree and } \\
\text { above (\%) }\end{array}$ & 29.6 & 15.6 & 1.3 & 87.5 & 33.7 & 18.1 & 2.3 & 85.3 \\
\hline $\begin{array}{l}\text { Median household income } \\
(2015 \$)\end{array}$ & 73,056 & 26,159 & 14,999 & 226,889 & 80,889 & 28,830 & 21,013 & 199,705 \\
\hline Median age (years) & 52 & 5 & 25 & 80 & 52 & 6 & 36 & 76 \\
\hline
\end{tabular}


Notes: Data consist of 3,777 prepaid systems and 12,801 PPA systems (16,078 total). Customer payments for PPA systems assume a $7 \%$ discount rate. Statistics for rebate levels are conditional on the system qualifying for a rebate. $\mathrm{HHI}$ refers to the Herfindahl-Hirschman Index.

The next set of variables reflects the market concentrations - that is, the distributions of market shares among competing firms - calculated from the TTS data set. Specifically, we calculate two versions of the Herfindahl-Hirschman Index (HHI) at the county level: one for all installed PV systems, and one for TPO systems only. ${ }^{13}$ Calculating the HHI for all systems relies only on knowledge of times, locations, and installer identifications, which are well-covered variables in the TTS data set. The calculation for TPO systems only also requires knowledge of the ownership arrangement of the system, which is included in the data set but has an unknown status for many observations. We use only the observations for which the status is known in constructing the measure, which raises some concerns about its accuracy. We assume our measure will at least capture the major trends among the large vertically integrated firms that dominated the TPO market over this period. The mean HHI for all systems does not differ significantly between PPAs and prepaid contracts, whereas the mean HHI for TPO systems only is higher for PPAs.

The next set of variables reflects system characteristics, including system size, whether the system was ground- or rooftop-mounted, the module efficiency, whether the installation included a direct current (DC) optimized inverter setup, and whether the modules were considered "premium." 14 For the most part, the mean values for these variables are similar across PPAs and prepaid contracts. The most notable difference is the use of premium modules $(20 \%$ for prepaid versus $8 \%$ for PPAs).

The next set of variables includes price indices for the two major components of system hardware: modules and inverters. Each system is matched to the corresponding quarterly BNEF module spot price based on the date and whether the system uses mono- or poly-crystalline panels. Systems are matched with the quarterly SEIA/GTM inverter prices based on whether the system includes a string or micro inverter. Overall, the mean prices of both components are higher for prepaid contracts than for PPAs, largely because component prices dropped substantially over the period, and prepaid contracts were more prevalent earlier in the data set.

The final set of variables contains Census tract-level demographic variables obtained from S\&P Global. They include population and owner-occupied housing density measures, population percentages for three levels of educational attainment (no high school diploma, high school diploma but no bachelor's degree, and bachelor's degree), median household income, and median householder age. Mean demographic variables are similar across PPAs and prepaid contracts, with the former tending to occur in slightly denser tracts and the latter tending to occur in tracts with slightly higher average incomes.

Beyond the variables in the table, another metric for comparing across PPAs and prepaid contracts is the returns generated for financiers. Specifically, we can use the system prices,

\footnotetext{
${ }^{13}$ The HHI is a unitless metric used to quantify market concentration. The formula for HHI in a market with $n$ firms is $H H I=\sum_{i=1}^{n} s_{i}^{2}$, where $s_{i}$ denotes firm $i$ 's market share. The HHI approaches zero in highly unconcentrated markets (i.e., markets with many low-volume firms) and takes on a maximum value of one in markets with a single installer.

${ }^{14}$ Premium-brand panel brands include LG Electronics, Panasonic, SunPower, and SolarWorld (Mond 2017).
} 
financial contract terms, and rebate values to calculate the internal rates of return (IRRs) for the financiers for all the systems in the data set. The IRR, which is one metric to characterize the return on investment, represents the discount rate at which the net present value (NPV) of the project is equal to zero, so investments with higher IRRs are profitable over a larger range of discount rates. The details of the IRR calculation are provided in Appendix A.

The IRR distributions for each contract type are illustrated in Figure 5. In general, prepaid contracts provide financiers with much greater IRRs (mean of 59\%) than do PPAs (14\%).

Moreover, the dispersion of the prepaid distribution is much greater (standard deviation of $41 \%$ ) than it is for PPAs (4\%). Finally, the prepaid distribution is right-skewed, with significant weight at very high IRR levels, while the PPA distribution is slightly left-skewed, with a significant proportion of projects associated with IRRs below 10\%. The high IRRs associated with prepaid contracts are primarily a function of discounting: because financiers receive payment up-front, those revenues are not discounted over the (usually) 20-year contract term. In turn, this allows financiers to offer lower per-watt prices to customers of prepaid systems compared to PPA customers.



Figure 5. IRR distributions for all PPAs (left) and prepaid contracts (right)

Finally, to provide additional context for the financial values for which we estimate pass-through levels, the state-level distributions of expected gross utility bill savings (top panel) and rebates (bottom) are summarized in Figure 6. As the figure shows, bill savings per watt in California tend to be higher than in the other states in our data set, which is a result of the relatively higher electricity prices and greater solar resource (i.e., more production per watt) found in the state. Other states — such as New York, Massachusetts, and Connecticut - have relatively high electricity prices, but a lesser solar resource. The situation is reversed in Arizona and Nevada. Comparing across PPAs and prepaid contracts, for the states that have a significant proportion of prepaid contracts (California, Massachusetts, and New Jersey), the distributions are similar, particularly in California, which provides the bulk of our observations. For both contract types in California, there is substantial dispersion in expected bill savings. 
The bottom panel of the figure summarizes the rebate distributions for the systems that received one. Rebate levels per watt vary substantially across states. Rebates were exceptionally high in Connecticut but only applied to two systems. Systems installed in New York also received large rebates, around $\$ 1 / \mathrm{W}$. On the opposite end, none of the systems installed in New Jersey reported receiving rebates. For most observations in the remaining states, rebates were less than $\$ 0.5 / \mathrm{W}$. This includes California, which had a median rebate of $\$ 0.17 / \mathrm{W}$ and an interquartile range of $\$ 0.17 / \mathrm{W}-\$ 0.21 / \mathrm{W}$.



Figure 6. Distributions of expected gross utility bill savings (top) and state and local rebates (bottom) by state and contract type 


\section{Pass-Through Estimation Approach}

Our empirical estimates of value pass-through are based on a two-equation linear regression model. Equation 1 represents the system price paid by a financier to an installer, and Equation 2 represents payment from a customer to a financier. The key righthand-side variables in each equation are expected gross utility bill savings and state and local rebates, for which our goal is to estimate passthrough. We estimate several versions of our model to gain insight into how pass-through rates change with market concentration levels, and how endogeneity of the relationship between system prices and customer payments might affect pass-through.

We specify each equation in its most general form and then discuss the constraints we impose for different iterations of the analysis. Formally, Equation 1 is cast as:

$$
\text { sysP }=\alpha_{1} I+\alpha_{2} I^{H H I, P P A}+\alpha_{3} \text { custP }+\alpha X+\theta+\varphi+\eta+\mu+\varepsilon
$$

Where $s y s P$ is the system price paid by a financier to an installer, $I$ is a vector of the expected gross utility bill savings for the first year after the system is installed and the amount of the state and local rebate the financier receives for the system, the term $I^{H H I, P P A}$ represents a vector of interaction terms between the bill savings and rebates with HHI and PPA, custP is the customer payment, and $X$ is a vector of control variables. Time-invariant mean differences in prices across installers and financiers are captured by $\theta$ and $\varphi$, respectively. Unobserved locational and time-varying factors are captured by county-level $(\eta)$ and month-level $(\mu)$ fixed effects. All other unobserved factors are captured by the error term, $\varepsilon$. In all our reported results, standard errors are clustered at the county level.

Other controls in $X$ pertain to component prices, system characteristics, and tract-level demographics. The controls include system size and its square as well as module and inverter price indices, which are assumed to be cost-shifters on the installation side, because modules and inverters are globally traded commodities. The model also includes controls for demographic and system characteristics. Both sets of variables are listed in Table 1 under the appropriate categories. The omitted educational attainment category is percent of the population with a high school diploma but not a bachelor's degree. These control variables are broadly consistent with models used in previous studies (Gillingham et al. 2016; Nemet et al. 2016; Pless and van Benthem 2017).

Similarly, Equation 2 is defined as follows:

$$
\operatorname{custP}=\beta_{1} I+\beta_{2} I^{H H I, P P A}+\beta_{3} \text { sysP }+\beta Z+\theta+\varphi+\eta+\mu+\varepsilon
$$

The structure of Equation 2 is very similar to the system price equation, because it includes as regressors expected bill savings, rebates, HHI and interactions, system and demographic characteristics, and analogous fixed effects. However, there are important differences. First, we include system price as a regressor in Equation 2, replacing customer payments as a regressor from Equation 1. Second, while controls $X$ include system size and component price indices in Equation $1, Z$ includes contract term details in Equation 2: escalator rates, down payment amounts, and contract lengths. Because these terms only apply to PPAs, we interact each of these variables with the PPA indicator variable. Finally, we allow separate fixed effects for prepaid contracts and PPAs. 
To identify average pass-through levels in both equations in our model, we rely on a wide range of controls as well as a rich set of fixed effects to control for any unobserved factors that could be correlated with expected bill savings or rebate levels. We estimate three primary specifications of the model, each with different parameter restrictions and assumptions. In the base specification, we estimate the model using equation-by-equation ordinary least-squares (OLS) without including any of the HHI terms. We also impose the assumption that system prices affect customer payments, but not vice versa. This is based on our conversations with the platform, which revealed that back-andforth negotiations between installers and financiers do not occur for individual systems. Instead, the customer financing arrangement is based on the quoted system price from the installer. However, there is a caveat to this assumption: though negotiations do not occur between financiers and installers for individual systems, financiers might provide incentives to installers for achieving sales targets by offering the installers' customers lower-priced PPAs and prepaid contracts. To address this possibility, we include an instrumental variables (IV) specification (the third specification described below).

In the second model specification, we supplement the base specification by including HHI as an explanatory variable in both equations. By interacting HHI with gross expected bill savings and rebates, we can examine whether pass-through rates are influenced by market concentration. If greater market concentration reflects greater potential for the exercise of market power, then we might expect greater capture of expected bill savings by financiers and/or installers due to the exercise of first-degree price discrimination. In the case of rebates, the effects of greater market power are ambiguous, depending also on the elasticities of supply and demand and the shape of the demand curve. ${ }^{15} \mathrm{We}$ also estimate this specification with two different HHI measures: one based on both home-owned and TPO installed residential systems, and one based on TPO systems only. This allows us to account for the possibility that the home-owned and TPO markets function as essentially separate markets.

In the third specification of the model, we attempt to account for the possibility that system prices and customer payments are determined simultaneously, i.e., that system prices are influenced by customer payments, as would be the case if installers set system prices in anticipation of the resulting customer payments. This model specification is the same as the base specification, except the system price equation includes customer payment as a regressor, and the model is estimated using IV to achieve identification. Identification of Equation 1 requires at least one variable that only influences the system price through its impact on customer payments; we use the contract terms of the financial arrangement between financiers and customers for this purpose.

Unfortunately, this requires us to omit prepaid contracts from the analysis, because they have no variation in contract terms beyond price. To identify Equation 2, we use the module and inverter price indices as variables that only impact customer payments through their impact on system prices.

\footnotetext{
${ }^{15}$ As derived in Weyl and Fabinger (2013), the pass-through rate of a tax under conditions of symmetric, imperfect competition is $\rho=\frac{1}{1+\frac{\theta}{\varepsilon_{\theta}}+\frac{\varepsilon_{D}-\theta}{\varepsilon_{S}}+\frac{\theta}{\varepsilon_{m s}}}$, with $\theta$ representing a conduct parameter that provides a measure of price markup above marginal cost, $\varepsilon_{D}$ representing the elasticity of demand, $\varepsilon_{S}$ representing the elasticity of supply, $\varepsilon_{\theta}$ representing the elasticity of the conduct parameter, and $\varepsilon_{m s}$ measuring the curvature of demand. The conduct parameter resides between zero for perfect competition and one for a pure monopoly. Because $\varepsilon_{S}$ is greater than zero, and $\varepsilon_{m s}$ can be, whether an increase in the value of $\theta$ increases or decreases the pass-through rate depends on the values of the other parameters in the formula.
} 


\section{Results}

In this section, we present the results from estimating our empirical model. The impacts of bill savings and rebates on pre-incentive system price (the system price paid by the financier to the installer) and customer payments (the amount paid by the end-use customer to the financier) are delineated. The interpretation of the results as pass-through or capture depend on the value and the transaction. In terms of system prices, rebates and bill savings are passed through from installer to financier if rebates and bill savings have no impact on the pre-incentive system price. Mathematically, pass-through is represented by a zero coefficient, while capture is represented by a positive and statistically significant coefficient. In terms of customer payments, rebates are passed through to customers in the form of lower customer payments, while bill savings are passed through if savings have no impact on customer payments. Mathematically, rebate passthrough to customer payments is represented by a negative coefficient (-1 represents perfect pass through), bill savings pass-through to customer payments is represented by a zero coefficient, rebate capture from customer payments is represented by a zero or positive coefficient, and bill savings capture from customer payments is represented by a positive coefficient. Figure 7 shows the symbols used in the results figures to represent capture and pass-through.



Pass-through: Incentive is passed-through. For rebates to customer payment, pass-through is mathematically represented by a statistically significant negative coefficient ( -1 equals perfect pass-through). For all other effects, pass-through is represented by a zero coefficient.

Capture: A significant portion of the incentive is not passed through, but is "captured" during the installer or financier transactions. For rebates to customer payments, capture is mathematically represented by a zero or positive coefficient. For all other effects, capture is represented by a statistically significant positive coefficient.

\section{Figure 7. Symbols used to represent capture and pass-through}

Our results provide evidence of capture of electricity bill savings and pass-through of rebates. We find some evidence that pass-through to customer payments for PPAs changes with market concentration. Finally, we find that the magnitude of estimated pass-through changes for PPAs if we account for simultaneity between system prices and customer payments using our IV model. All models have $\mathrm{R}^{2}$ values above 0.5 , meaning that the variables in the models account for more than half of the variation in system prices or customer payments. The variables are stronger predictors of customer payments than system prices. $\mathrm{R}^{2}$ values are provided in Appendix B.

\subsection{Base Model Specification}

The results from our base model specification are summarized in Figure 8. Appendix B (Table B-1) shows detailed results. The numeric values in the all of the results figures can be interpreted as the change in system price or customer payment $(\$ / \mathrm{W})$ resulting from a $\$ 1 / \mathrm{W}$ change in the incentive level. The middle column of the figure shows the results of OLS estimation of Equation 1 (incentive impacts on system price), and the last column corresponds with the results of estimating Equation 2 (incentive impacts on customer payments). Recall that the expected gross savings variable represents expected first-year savings. Below we calculate, given 
assumptions about the discount rate and how electricity prices will increase, the pass-through rate of expected gross savings over the duration of the contract.

\section{System Price}

Expected gross savings: Prepaid

Expected gross savings: PPAs

Rebates: Prepaid

Rebates: PPAs



2.32

0.49

0.31
Customer Payment



$\triangle 1.68$



Figure 8. Results from base model specification

From estimation of Equation 1, we find a positive and significant relationship between higher expected bill savings and system prices for both prepaid contracts and PPAs, providing evidence of capture. However, we find the impacts differ significantly across the contract types. For systems that are financed upfront, an extra dollar per watt of expected bill savings in the first year of system production is associated with an $\$ 0.85 / \mathrm{W}$ increase in the system price, while the same increase in expected bill savings is associated with a $\$ 2.32 / \mathrm{W}$ increase in the system price for PPAs.

We also find that higher levels of state and local rebates are associated with higher system prices, again consistent with capture. At the high end, we find that an extra $\$ 1 / \mathrm{W}$ rebate corresponds to a $\$ 0.49 / \mathrm{W}$ increase in system price for prepaid contracts. At the low end, we find an analogous effect of $\$ 0.31 / \mathrm{W}$ for PPAs. The difference between the two, however, is not statistically significant.

Examining the estimated coefficients on the other variables yields a mixture of expected and surprising results (see Table B-1 in Appendix B). The coefficient on the inverter price index is positive as expected and is estimated very precisely. However, the coefficient on the module index is unexpectedly negative, and, while significant, less precisely estimated. One possible explanation for this result is our use of monthly fixed effects, which could be capturing most of the overall downward trend in module prices. Comparing across contract types, PPA systems are associated with $\$ 0.69 / \mathrm{W}$ lower system prices on average, which could result from a selection effect in which PPA customers tend to require lower contract prices (and hence lower system prices) to finalize the transaction.

The last set of coefficients listed in Table B-1 pertain to system characteristics, most of which are statistically significant. The coefficients on system size and its square are consistent with economies of scale with diminishing marginal returns. Ground-mounted systems, for which there are very few in the dataset, are associated with higher system prices, while the effect of module test ratings is insignificant. Finally, systems with DC-optimized inverters tend to have higher 
prices, while systems with premium panels tend to have lower prices. The latter could be due to collinearity with our fixed effects, and the relatively small proportion of systems featuring premium panels $(<10 \%)$.

From estimation of Equation 2, we find a positive and significant relationship between higher expected bill savings and customer payments for both prepaid contracts and PPAs (Figure 8). As was the case for system prices, the effect is much stronger for PPAs: an additional \$1/W of expected bill savings is associated with a $\$ 1.68 / \mathrm{W}$ increase in customer payments, compared with a $\$ 0.26 / \mathrm{W}$ increase for prepaid contracts.

For state and local rebates, we find a significant and negative relationship with customer payments, which is consistent with rebate pass-through from financiers to customers. The passthrough rate to customer payments for prepaid contracts is $-\$ 0.61 / \mathrm{W}$ for an additional $\$ 1 / \mathrm{W}$ in rebate level, compared with $-\$ 0.57 / \mathrm{W}$ for PPAs. Again, as was the case for system prices, the difference between the two is not statistically significant.

The customer payment equation also includes an estimate of the effect of the installer's system price on customer payments (see Table B-1 in Appendix B). We find that, for prepaid contracts, an additional $\$ 1 / \mathrm{W}$ in the system price is associated with a $\$ 0.77 / \mathrm{W}$ increase in customer payments. This value is much higher than the effect for PPAs, which is only $\$ 0.34 / \mathrm{W}$. One potential explanation for this difference could be that market demand for PPAs is more elastic than the demand for prepaid contracts, forcing financiers to bear more of the system cost in PPA transactions. Another possibility is that the 7\% discount rate we assumed in calculating the customer payment variable does not reflect the true market dynamics. For example, if we assume no discounting, there is no statistically significant difference in the effects of system price on customer payments between prepaid contracts and PPAs.

Several contract variables also have a significant association with customer payments. We find that customer payments are, on average, $\$ 2.41 / \mathrm{W}$ higher for PPAs than for prepaid contracts, which illustrates the considerable benefit accruing to customers who can make large upfront payments. We also find that price escalators are associated with higher customer payments, suggesting that, given a 7\% discount rate, any lowering of the initial per-kWh PPA price resulting from agreeing to a price escalator has a smaller effect on total customer payment than the direct impact on price of the escalator. Not surprisingly, we find that longer terms are associated with greater payments. We also find that down payments have no significant effect on payments.

Finally, we estimate statistically significant relationships between several of the system characteristics variables and customer payments. Because financiers own the systems and therefore are responsible for their maintenance, these characteristics could influence expected future costs. The relationship between system size and customer payment (decreasing and convex) is qualitatively the same as for system prices. Also, as was the case with system prices, estimation of the customer payment equation reveals positive and significant coefficients for ground-mounted systems and systems with DC-optimized inverters. Finally, module PTC ratings have a negative relationship with customer payments, but the effect is small (a one standard deviation increase in rating is associated with a $\$ 0.06 / \mathrm{W}$ increase in customer payment). 
We can combine the estimation results from our base model specification to calculate the "total" pass through rate, meaning the pass-through rate from the initial transaction to the end-use customer. The results for both expected bill savings and rebates are summarized in Figure 9 for both contract types (Table B-2 in Appendix B shows detailed results). The figure decomposes pass-through into a direct system price effect estimated in Equation 1, a system price effect on payment that multiplies the direct system price effect by the estimated pass-through of system price to customer payments from Equation 2, and a direct customer payment effect estimated in Equation 2. ${ }^{16}$



Figure 9. Value pass-through decomposition by contract type

Overall, we find that expected bill savings are captured, while rebates are passed through. For prepaid contracts, an additional $\$ 1 / \mathrm{W}$ of expected bill savings in the first year is associated with a $\$ 0.91 / \mathrm{W}$ increase in the discounted customer payment. For PPAs, the result is a $\$ 2.48 / \mathrm{W}$ increase. Another way to interpret these results is from the perspective of an additional $\$ 1 / \mathrm{W}$ of expected bill savings over the duration of the contract, rather than just the first year. If we assume the retail rate for utility electricity increases at 5\% per year and the contract lasts 20 years, then an additional $\$ 1 / \mathrm{W}$ of expected bill savings over the life of the contract is associated with a $\$ 0.06 / \mathrm{W}$ increase in customer payment for prepaid contracts and $\$ 0.16 / \mathrm{W}$ increase in the discounted customer payment for PPAs.

Another key difference in the expected bill savings results across contract types is the relative contributions of system prices and customer payments to total capture. In the case of prepaid contracts, most of the increase in customer payments associated with additional expected bill savings comes from capture of system prices. This is largely due to the roughly $80 \%$ capture rate of system price to customer payment for this type of contract. In the case of PPAs, most of the total increase in customer payment comes through the direct customer payment effect. This is the case even though the system price effect is large because of the relatively low capture rate of system price to customer payment.

\footnotetext{
${ }^{16}$ Mathematically, the direct system price effect corresponds to estimates of $\alpha_{1,0}$ for prepaid contracts and $\alpha_{1,0}+$ $\alpha_{2,0}$ for PPAs, the system price pass-through effect corresponds to estimates of $\alpha_{1,0} \cdot \beta_{3,0}$ for prepaid contracts and $\left(\alpha_{1,0}+\alpha_{2,0}\right) \cdot \beta_{3,0}$ for PPAs, and the direct customer payment effect corresponds to estimates of $\beta_{1,0}$ for prepaid contracts and $\beta_{1,0}+\beta_{2,0}$ for PPAs.
} 
The estimated total pass-through rate for state and local rebates is greater for PPAs than for prepaid contracts (right column, bottom row in Figure 9). In total, a portion of state and local rebates is passed through, on average, to customers in the form of lower payments, though only the estimate for PPAs $(-\$ 0.47 / \mathrm{W}$ for an additional $\$ 1 / \mathrm{W}$ rebate) is statistically significant. Interestingly, the lower and non-significant result for prepaid contracts arises despite greater (in magnitude) direct customer payment effects (row 3 ) for prepaid contracts. The capture of rebates in the form of higher system prices, as well as the high pass-through rate of system prices to customer payments, reduce the total pass-through of rebates for prepaid systems.

We can compare our results for rebate pass-through to the findings from Pless and van Benthem (2017). In contrast to our multi-equation model, the authors of that study directly estimate the total impact of rebates on customer payments, which corresponds to the right column, bottom row in Figure 9. They find pass-through over-shifting, suggesting customer payments declined by more than the rebate amount and more than observed in our results. One potential reason for the differences is that our data set is restricted to installations funded through the platform, while their data set is sampled from the entire universe of systems eligible for the California Solar Initiative. This excludes from our analysis large, vertically integrated installers that provide both installation services and financing. To the extent that those firms pursue different pricing strategies or operate under different market conditions (including the possibility of operating in different markets) than the firms in our data set, differences in results are to be expected. Another factor that might contribute to differences in results is the period under study, because their data set is based on installations from an earlier period (2010-2012) than ours (2012-2015). The residential PV market has been rapidly changing over the past decade, so differences could reflect changes in supply and demand conditions over time as firms exit and enter the market and the profiles of new customers change.

\subsection{Concentration Interactions}

Here we estimate the relationships between pass-through/capture rates and market concentration; the results are summarized in Table 2. The left panel contains the results using HHI based on all systems, while the right panel contains the results from using HHI based on only TPO systems. For the estimation, we standardize the HHI variable so that the estimated coefficient represents the effect of a one standard deviation change in HHI.

For the all-systems HHI concentration measure, we find a limited impact of HHI on the estimated pass-through/capture rates - particularly for the customer payment equation, for which none of the HHI interaction terms have significant coefficients. For the system price equation, the expected bill savings and $\mathrm{HHI}$ interaction terms have insignificant coefficients. Pass-through of rebates to system prices decreases with HHI for prepaid contracts, but not for PPAs.

Using the TPO-only HHI measure, we find similar results for the system price equation, but the customer payment equation yields key differences. First, the interaction between expected bill savings and HHI for PPA is positive and significant at the $10 \%$ level. Second, the effect of system price on customer payments declines with HHI for PPAs. Finally, the interaction term between HHI and the PPA indication suggests a positive relationship between customer payments and market concentration. Taken together, the results presented in Table 2 suggest it is important to consider concentration measures based on the TPO market specifically when assessing pricing and pass-through. 
Table 2. Results from Model Specification with Market Concentration

\begin{tabular}{|c|c|c|c|c|}
\hline & \multicolumn{2}{|c|}{ All systems concentration } & \multicolumn{2}{|c|}{ TPO-only concentration } \\
\hline & System price & $\begin{array}{l}\text { Customer } \\
\text { payment }\end{array}$ & System price & $\begin{array}{l}\text { Customer } \\
\text { payment }\end{array}$ \\
\hline Savings & $\begin{array}{l}1.124^{* * *} \\
(0.403)\end{array}$ & $\begin{array}{l}0.285^{* * *} \\
(0.080)\end{array}$ & $\begin{array}{l}1.014^{* * *} \\
(0.338)\end{array}$ & $\begin{array}{l}0.280^{* * *} \\
(0.079)\end{array}$ \\
\hline Savings $\times \mathrm{HHI}$ & $\begin{array}{l}-0.270 \\
(0.218)\end{array}$ & $\begin{array}{l}-0.028 \\
(0.066)\end{array}$ & $\begin{array}{l}-0.148 \\
(0.172)\end{array}$ & $\begin{array}{l}-0.024 \\
(0.047)\end{array}$ \\
\hline Savings $\times$ PPA & $\begin{array}{l}1.354^{* * *} \\
(0.391)\end{array}$ & $\begin{array}{l}1.429^{* * *} \\
(0.203)\end{array}$ & $\begin{array}{l}1.414^{\star \star \star} \\
(0.304)\end{array}$ & $\begin{array}{l}1.047^{* * *} \\
(0.239)\end{array}$ \\
\hline Savings $\times \mathrm{PPA} \times \mathrm{HHI}$ & $\begin{array}{c}0.173 \\
(0.218) \\
\end{array}$ & $\begin{array}{c}0.006 \\
(0.116)\end{array}$ & $\begin{array}{c}0.090 \\
(0.161) \\
\end{array}$ & $\begin{array}{l}0.184^{*} \\
(0.106)\end{array}$ \\
\hline Rebate & $\begin{array}{l}0.832^{\star \star \star} \\
(0.230)\end{array}$ & $\begin{array}{c}-0.811^{\star * \star} \\
(0.203)\end{array}$ & $\begin{array}{l}0.876^{\star \star \star *} \\
(0.273)\end{array}$ & $\begin{array}{c}-0.717^{\star \star \star} \\
(0.186)\end{array}$ \\
\hline Rebate $\times \mathrm{HHI}$ & $\begin{array}{l}-0.223^{\star *} \\
(0.088)\end{array}$ & $\begin{array}{c}0.188 \\
(0.133)\end{array}$ & $\begin{array}{l}-0.199^{*} \\
(0.114)\end{array}$ & $\begin{array}{c}0.134 \\
(0.095)\end{array}$ \\
\hline Rebate $\times$ PPA & $\begin{array}{l}-0.472^{* *} \\
(0.220)\end{array}$ & $\begin{array}{c}0.243 \\
(0.226)\end{array}$ & $\begin{array}{c}-0.507^{* *} \\
(0.232)\end{array}$ & $\begin{array}{c}0.071 \\
(0.252)\end{array}$ \\
\hline Rebate $\times \mathrm{PPA} \times \mathrm{HHI}$ & $\begin{array}{l}0.185^{*} \\
(0.083)\end{array}$ & $\begin{array}{l}-0.158 \\
(0.136) \\
\end{array}$ & $\begin{array}{c}0.207^{\star} \\
(0.109) \\
\end{array}$ & $\begin{array}{c}-0.079 \\
(0.119) \\
\end{array}$ \\
\hline System price & & $\begin{array}{l}0.780^{* * *} \\
(0.038)\end{array}$ & & $\begin{array}{l}0.782^{* * \star} \\
(0.034)\end{array}$ \\
\hline System price $\times \mathrm{HHI}$ & & $\begin{array}{l}-0.009 \\
(0.017)\end{array}$ & & $\begin{array}{l}-0.012 \\
(0.015)\end{array}$ \\
\hline System price $\times$ PPA & & $\begin{array}{c}-0.433^{* * \star} \\
(0.069)\end{array}$ & & $\begin{array}{c}-0.271^{* * *} \\
(0.063)\end{array}$ \\
\hline System price $\times$ PPA $\times \mathrm{HHI}$ & & $\begin{array}{c}0.006 \\
(0.027)\end{array}$ & & $\begin{array}{c}-0.074^{\star * *} \\
(0.028)\end{array}$ \\
\hline PPA & $\begin{array}{c}-0.719^{* * *} \\
(0.135)\end{array}$ & $\begin{array}{l}2.398^{* * *} \\
(0.289)\end{array}$ & $\begin{array}{c}-0.673^{* \star *} \\
(0.114)\end{array}$ & $\begin{array}{l}1.620^{* * *} \\
(0.284)\end{array}$ \\
\hline $\mathrm{HHI}$ & $\begin{array}{c}0.046 \\
(0.068)\end{array}$ & $\begin{array}{c}0.023 \\
(0.067)\end{array}$ & $\begin{array}{l}0.005 \\
(0.064)\end{array}$ & $\begin{array}{c}0.027 \\
(0.054)\end{array}$ \\
\hline $\mathrm{PPA} \times \mathrm{HHI}$ & $\begin{array}{c}-0.002 \\
(0.067) \\
\end{array}$ & $\begin{array}{l}-0.050 \\
(0.096)\end{array}$ & $\begin{array}{l}-0.023 \\
(0.051)\end{array}$ & $\begin{array}{l}0.250^{* * * x} \\
(0.097)\end{array}$ \\
\hline $\begin{array}{l}\text { Observations } \\
\mathrm{R}^{2} \\
\text { Adjusted } \mathrm{R}^{2}\end{array}$ & $\begin{array}{l}16,078 \\
0.595 \\
0.590\end{array}$ & $\begin{array}{l}16,078 \\
0.897 \\
0.895\end{array}$ & $\begin{array}{l}16,078 \\
0.595 \\
0.590\end{array}$ & $\begin{array}{l}16,078 \\
0.899 \\
0.896\end{array}$ \\
\hline $\begin{array}{l}\text { Notes: Standard errors (in p } \\
\text { denote statistical significanc } \\
\text { system characteristics (syst } \\
\text { mounting, DC-optimized inv } \\
\text { (population density, owner-c } \\
\text { population without a high sc } \\
\text { and fixed effects for installe } \\
\text { regressions also include cor } \\
\text { the PPA indicator variable }\end{array}$ & $\begin{array}{l}\text { htheses) are clu } \\
\text { the } 10 \%, 5 \%, a \\
\text { size and its squ } \\
\text { rs, and premiun } \\
\text { upied housing de } \\
\text { I diploma, and } \\
\text { inanciers, count } \\
\text { ct variables (esc }\end{array}$ & $\begin{array}{l}\text { ed at the cc } \\
1 \% \text { levels, } \\
\text { module PT } \\
\text { nels), tract- } \\
\text { ty, median } \\
\text { entage of } p \\
\text { and quote } \\
\text { ion rate, do } \\
\text { the fixed }\end{array}$ & $\begin{array}{l}\text { level. The syn } \\
\text { ctively. All reg } \\
\text { tes, and dumm } \\
\text { demographic } \\
\text { median income } \\
\text { ation with a bac } \\
\text { hs. The custon } \\
\text { ayment, and te }\end{array}$ & $\begin{array}{l}{ }^{*},{ }^{* *}, \text { and }{ }^{* * *} \\
\text { ons include } \\
\text { or ground- } \\
\text { ols } \\
\text { centage of } \\
\text { r's degree), } \\
\text { ayment } \\
\text { interacted with } \\
\text { cator variable }\end{array}$ \\
\hline
\end{tabular}

\subsection{Instrumental Variables}

The results presented so far assume that system price and customer payments are not determined simultaneously; to test that assumption, we estimate the model using an instrumental variables (IV) approach. The variables used to identify the impact of system price on customer payment 
are the module and inverter indices, which are assumed to shift installer costs but not be correlated with the error term in the customer payment equation. The variables used to identify the impact of customer payment on system price are the contract variables. Because these variables either do not apply or exhibit no variation in the data set for prepaid contracts, we can only estimate this model on the PPA subset of the data.

The results from estimating the IV model are summarized in Figure 10 (see Table B-3 in Appendix B for detailed results). The first-stage OLS estimation is presented in the left column, while the full IV model estimation is presented in the right column. The IV model is estimated using two-stage least squares. The precision of the estimates makes three-stage least squares estimation unnecessary.

The first-stage OLS results reveal most of the estimates of interest to be statistically significant in both the system price and customer payment equations. An F-test for joint significance of the module and inverter price indices in the system price equation yields a test statistic of 44, suggesting that the IV used to identify the customer payment equation are relevant. The same test for the contract variables in the customer payment equation yields a test statistic of 955 , suggesting that the IV used to identify the system price equation are relevant. Under our assumption that these variables are also exogenous, we proceed to the results of the full IV estimation.

From the full model estimation, we observe differences between the estimates from our base specification. Most notably, we estimate a positive and significant effect of system price on customer payments: a $\$ 0.50 / \mathrm{W}$ increase in system price is associated with a $\$ 1 / \mathrm{W}$ increase in customer payment (Table B-3). This suggests that, at least for PPA systems, system pricing depends in part on the contract between customers and financiers. In addition, our estimate of the effect of system price on customer payments is much higher (and closer to the prepaid result): $\$ 0.64 / \mathrm{W}$ in the IV model versus $\$ 0.34 / \mathrm{W}$ in the base specification.

The direct capture rates for expected bill savings are lower in both equations. For system prices, the capture rate is estimated to be $\$ 1.14 / \mathrm{W}$ (vs. $\$ 2.32 / \mathrm{W}$ in the base specification). For customer payments, the capture rate is estimated to be $\$ 0.95 / \mathrm{W}$ (vs. $\$ 1.68 / \mathrm{W}$ in the base specification). As illustrated for the base specification in Figure 9, we can combine these estimates to calculate the total average capture of expected bill savings. To calculate the total capture, we once again need to account for capture in both equations. Unlike in Figure 9, however, there is an additional effect to account for: the effects of system prices on customer payments. Therefore, total capture is calculated as $\$ 0.50 \times(\$ 1.14+\$ 0.64 \times \$ 0.95)+\$ 0.95=\$ 1.98 / \mathrm{W}$, which is about $20 \%$ less than the $\$ 2.48 / \mathrm{W}$ estimate from Figure 9 for the base specification.

In contrast, the direct pass-through/capture estimates for rebates in the IV model are similar in magnitude and direction to the estimates from the base specification. For system prices, the capture rate is estimated to be $\$ 0.49 / \mathrm{W}$ (compared to $\$ 0.33 / \mathrm{W}$ in the base specification). For customer payments, the pass-through rate is estimated to be $\$-0.63 / \mathrm{W}$ (vs. $\$-0.42 / \mathrm{W}$ in the base specification). By combining the estimates, we calculate a total average pass-through of $\$ 0.50 \times$ $(\$ 0.49-\$ 0.64 \times \$ 0.63)-\$ 0.63=\$-0.52 / \mathrm{W}$, which is about $11 \%$ greater than the $\$-0.47 / \mathrm{W}$ estimate from Figure 9 for the base specification. 




Figure 10. Results from the IV specification (PPAs only)

Taken together, the IV model results suggest that the results on value pass-through may be biased under the assumptions we made for the base model. However, the IV and base estimates are not remarkably different. To the extent that systems sold as prepaid contracts exhibit similar behavior (or are more consistent with the base specification assumptions), the estimates from the base specification are still useful points of analysis. 


\section{Conclusion}

This report adds three new elements to the existing literature on PV markets. One, it estimates value pass-through across two separate links in the supply chain-system installation and financing - as opposed to combining them. Two, it separately estimates the degree of passthrough for customer electricity bill savings and state and local rebates. And three, it estimates separate effects for different financing products: PPAs and prepaid contracts.

Our analysis finds evidence that electricity bill savings are captured by installers and financiers, while rebates are passed through to PV adopters. Moreover, we document differences in the levels of pass-through for different contract types: total capture and pass-through to customer payments for electricity bill savings and rebates, respectively, is greater for PPAs than for prepaid contracts. We find some evidence that pass-through rates to customer payments for PPAs change with market concentration: installers capture more of the value of bill savings in more concentrated markets.

These results yield two implications. First, the financial benefits of bill savings and up-front rebates accrue to installers and customers in different ways in TPO markets. Our results indicate that the value of bill savings mostly accrue to installers in the form of higher margins, while the value of rebates largely accrue to customers in the form of lower prices. Second, we find evidence that more competitive markets - meaning markets where customers have access to more quotes from more installers - curb the ability of installers to capture the value of bill savings and possibly force installers to pass the value of rebates through to customers. This result competitive PV markets result in higher value accrual to end-use PV customers and possibly in higher PV deployment.

We derive these conclusions by analyzing multiple years of transactional data from a major customer finance firm in the U.S. residential market. Because the finance platform acts as a market intermediary, connecting both system installers and customers, we can understand interactions between the cost of system installation, the allocation of financial incentives, and the price offered to consumers. Importantly, the specificity of the data set allows us to control for mean unobserved temporal, locational, installer, and financier effects. 


\section{References}

Abratt, Russell, and Leyland Pitt. 1985. "Pricing Practices in Two Industries." Industrial Marketing Management 14: 301-6.

Barbose, Galen, and Naïm Darghouth. 2017. "Tracking the Sun X: The Installed Price of Residential and Non-Residential Photovoltaic Systems in the United States." LBNL-2001062. Berkeley, CA: Lawrence Berkeley National Laboratory. https:/emp.lbl.gov/publications/tracking-sun-10-installed-price/.

BNEF. 2016. "Solar Module Price Index.” Solar Price Indexes. 2016. https://surveys.bnef.com/solar/module-price.

Cannon, H., and F. Morgan. 1990. "A Strategic Pricing Framework.” Journal of Service Marketing 4: 19-30.

Davidson, Carolyn, and Robert Margolis. 2015. "Selecting Solar: Insights into Residential Photovoltaic (Pv) Quote Variation.” NREL/TP--6A20-64792. Golden, CO: National Renewable Energy Laboratory. http://www.osti.gov/scitech/biblio/1225927-selecting-solar-insightsresidential-photovoltaic-pv-quote-variation.

Davidson, Carolyn, and Daniel Steinberg. 2013. "Evaluating the Impact of Third-Party Price Reporting and Other Drivers on Residential Photovoltaic Price Estimates." Energy Policy 62 (November): 752-61. https://doi.org/10.1016/j.enpol.2013.07.112.

Davidson, Carolyn, Daniel Steinberg, and Robert Margolis. 2015. "Exploring the Market for Third-Party-Owned Residential Photovoltaic Systems: Insights from Lease and Power-Purchase Agreement Contract Structures and Costs in California." Environmental Research Letters 10 (2): 024006. https://doi.org/10.1088/1748-9326/10/2/024006.

Dong, C. G., Ryan Wiser, and Varun Rai. 2014. "Incentive Pass-through for Residential Solar Systems in California.” Technical Report LBNL-6927E. United States: Lawrence Berkeley National Laboratory. https://doi.org/10.2172/1170590.

Gillingham, K., H. Deng, R.H. Wiser, N. Darghouth, G. Nemet, G.L. Barbose, V. Rai, and C. Dong. 2016. "Deconstructing Solar Photovoltaic Pricing: The Role of Market Structure, Technology, and Policy." The Energy Journal 37 (3): 231-50.

Hinterhuber, Andreas. 2008a. "Customer Value-Based Pricing Strategies: Why Companies Resist.” Journal of Business Strategy 29 (4): 41-50.

_. 2008b. "Value Delivery and Value-Based Pricing in Industrial Markets." In Creating and Managing Superior Customer Value. Vol. 14. UK: Emerald Group Publishing.

Indounas, Kostis. 2006. "Making Effective Pricing Decisions.” Business Horizons 49: 415-24.

Ingenbleek, Paul, Marion Debruyne, Ruud Frambach, and Theo Verhallen. 2003. "Successful New Product Pricing Practices: A Contingency Approach.” Marketing Letters 14 (4): 289-305. 
Kortge, G. Dean, and Patrick A. Okonkwo. 1993. "Perceived Value Approach to Pricing." Industrial Marketing Management 22 (133-140).

Lambrecht, Anja, Katja Seim, Naufel Vilcassim, Amar Cheema, Yuxin Chen, Gregory S. Crawford, Kartik Hosanagar, et al. 2012. "Price Discrimination in Service Industries." Marketing Letters 23: 423-38.

Lorentziadis, Panos. 2016. "Optimal Bidding in Auctions from a Game Theory Perspective." European Journal of Operational Research 248: 347-71.

McAfee, R. Preston, and John McMillan. 1987. "Auctions and Bidding." Journal of Economic Literature 25 (2).

Merler, Silvia. 2017. "Big Data and First-Degree Price Discrimination.” Bruegel (blog). February 20, 2017. http://bruegel.org/2017/02/big-data-and-first-degree-price-discrimination/.

Milgrom, Paul. 1989. "Auctions and Bidding: A Primer." The Journal of Economic Perspectives 3 (3): 3-22.

Mond, Allison. 2017. "Module Procurement Trends in the U.S. Residential Market." Washington, D.C.: GTM Research.

Monroe, K. 2002. Pricing - Making Profitable Decisions. 3rd. New York, NY: McGraw Hill.

Nemet, Gregory, Eric O’Shaughnessy, Ryan H. Wiser, Naïm R. Darghouth, Galen L. Barbose, Kenneth Gillingham, and Varun Rai. 2016. "Characteristics of Low-Priced Solar Photovoltaic Systems in the United States.” LBNL-1004062. Lawrence Berkeley National Laboratory. https://emp.lbl.gov/publications/characteristics-low-priced-solar.

NREL. 2017. “Utility Rate Database.” OpenEI. 2017. https://openei.org/wiki/Utility_Rate_Database.

Pless, Jacquelyn, and Arthur A. van Benthem. 2017. "The Surprising Pass-Through of Solar Subsidies." Working Paper 23260. National Bureau of Economic Research.

https://doi.org/10.3386/w23260.

Pless, Jacquelyn, Ria Langheim, Christina Machak, Henar Hellow, and Ben Sigrin. 2017. "The Price-Concentration Relationship in Early Residential Solar Third-Party Markets.” Technical Report NREL/TP-6A20-66784. United States: National Renewable Energy Laboratory. https://doi.org/10.2172/1342827.

Rai, Varun, and Benjamin Sigrin. 2013. "Diffusion of Environmentally-Friendly Energy Technologies: Buy versus Lease Differences in Residential PV Markets.” Environmental Research Letters 8 (1): 014022. https://doi.org/10.1088/1748-9326/8/1/014022.

Riley, John, and William Samuelson. 1981. "Optimal Auctions.” The American Economic Review 71 (3): 381-92. 
Rothkopf, Michael, and Ronald Harstad. 1994. "Modeling Competitive Bidding: A Critical Essay.” Management Science 40 (3): 364-84.

SEIA/GTM Research. 2013. "2012 Year in Review.” U.S. Solar Market Insight. Washington, D.C.: Solar Energy Industries Association/GTM Research.

—. 2014. “2013 Year in Review.” U.S. Solar Market Insight. Washington, D.C.: Solar Energy Industries Association/GTM Research.

—. 2015. “2014 Year in Review.” U.S. Solar Market Insight. Washington, D.C.: Solar Energy Industries Association/GTM Research.

—. 2016. “2015 Year in Review.” U.S. Solar Market Insight. Washington, D.C.: Solar Energy Industries Association/GTM Research.

Shiller, Ben. 2016. "Personalized Price Discrimination Using Big Data." 108. Working Papers. Brandeis University, Department of Economics and International Businesss School.

https://ideas.repec.org/p/brd/wpaper/108.html.

Weyl, E. Glen, and Michal Fabinger. 2013. "Pass-Through as an Economic Tool: Principles of Incidence under Imperfect Competition.” Journal of Political Economy 121 (3): 528-83.

https://doi.org/10.1086/670401. 


\section{Appendix A. Internal Rate of Return Calculation}

To calculate IRR for each system in the data set, we first must specify the formula for NPV, set it equal to zero, and then solve for the discount rate with everything else in the formula treated as a parameter. Our NPV formula is the following:

$$
\begin{aligned}
N P V=- & \text { Cost }+U p P m t+\sum_{t=0}^{T}\left(\frac{1}{1+r}\right)^{t} \cdot(1+E s C)^{t-1} \cdot \text { Price }_{1} \cdot\left(1+\text { Deg }^{t-1} \cdot \text { Prod }_{1}\right. \\
& +\frac{1}{1+r} \cdot I T C \cdot \operatorname{Cost}+\frac{1}{1+r} \cdot M T R \cdot B D \cdot(1-0.5 \cdot I T C) \cdot \text { Cost }^{7} \\
& +\sum_{t=1}^{7}\left(\frac{1}{1+r}\right)^{t} \cdot M T R \cdot D R_{t} \cdot(1-B D) \cdot(1-0.5 \cdot I T C) \cdot \text { Cost }
\end{aligned}
$$

where Cost is the amount that the financier pays the installer for the system; UpPmt includes full payment for system production in the case of a prepaid contract, or a down payment amount for PPAs and leases; EsC represents the escalation rate of the PPA or lease price; Price $_{1}$ represents the per-kWh power price in the first year of the contract; Deg represents the degradation rate of system production (assumed to be $0.5 \%$ per year); $\operatorname{Prod}_{1}$ denotes expected system production in the first year of the contract; ITC reflects the investment tax credit, which is $30 \%$ of the system cost; MTR denotes the marginal corporate tax rate (assumed here to be $35 \%) ; B D$ represents the percentage of the depreciable basis eligible for bonus depreciation (50\%); and $D R_{t}$ represents the depreciation rate of the system $t$ years after the system is installed based on the Modified Accelerated Cost Recovery System (MACRS) schedule.

A few notes on customer payments and depreciation are in order. First, for leases, the degradation rate does not apply, because customers pay a fixed monthly amount (subject to escalation) regardless of production level. Second, depreciation of the system applies to its depreciable basis. In this case, the depreciable basis is the cost of the system minus half of the ITC value (in other words, $85 \%$ of the cost of the system). Half of the depreciable basis can be depreciated in the first year through bonus depreciation. Over the next 5 years, the rest of the depreciable basis can be depreciated according to the MACRS schedule $(20 \%, 32 \%, 19.2 \%$, $11.52 \%, 11.52 \%$, and $5.76 \%$ in years 2 through 7 , respectively).

Finally, the major caveat underlying our IRR calculation is that it does not account for maintenance of the system, which, as owner, the financier is responsible for. As such, our IRR calculations likely represent an upper bound. 


\section{Appendix B. Detailed Regression Results}

The tables below provide detailed results in support of the result summaries in Section 5. Table B-1 and Table B-2 relate to Section 5.1. Table B-3 relates to Section 5.3.

Table B-1. Results from Base Model Specification Units $=2015 \$ / \mathrm{W}$




Table B-2. Value Pass-Through Decomposition by Contract Type

\begin{tabular}{lcc|cc}
\multicolumn{3}{c}{ Units $=2015 \$ / \mathrm{W}$} \\
\hline & \multicolumn{2}{c}{ Expected bill savings } & \multicolumn{2}{c}{ Rebates } \\
\cline { 2 - 5 } & Prepaid & PPA & Prepaid & PPA \\
\hline \multirow{2}{*}{ System price effect } & $0.849^{* * *}$ & $2.316^{* * *}$ & $0.494^{* *}$ & $0.306^{* * *}$ \\
& $(0.22)$ & $(0.12)$ & $(0.16)$ & $(0.09)$ \\
System price pass-through effect & $0.652^{* * *}$ & $0.794^{* * *}$ & $0.379^{* *}$ & $0.105^{* * *}$ \\
Customer payment effect & $(0.17)$ & $(0.08)$ & $(0.12)$ & $(0.03)$ \\
& $0.257^{* * *}$ & $1.682^{* * *}$ & $-0.614^{* * *}$ & $-0.571^{* * *}$ \\
Total & $(0.03)$ & $(0.07)$ & $(0.10)$ & $(0.08)$ \\
\hline
\end{tabular}

Notes: Results are derived from the base model specification summarized in Table B-1. Standard errors (in parentheses) are clustered at the county level. The symbols ${ }^{*},{ }^{* *}$, and ${ }^{* * *}$ denote statistical significance at the $10 \%, 5 \%$, and $1 \%$ levels, respectively. All regressions include tract-level demographic controls (population density, owner-occupied housing density, median age, median income, percentage of population without a high school diploma, and percentage of population with a bachelor's degree) and fixed effects for installers, financiers, counties, and quote months. The customer payment regressions also include interactions between the fixed effects and the PPA indicator variable. 
Table B-3. Results from the IV Specification (PPAs only)



Notes: Standard errors (in parentheses) are clustered at the county level. The symbols *, ${ }^{* *}$, and ${ }^{* *}$ denote statistical significance at the $10 \%, 5 \%$, and $1 \%$ levels, respectively. All regressions include system characteristics (system size and its square, module PTC rates, and dummies for groundmounting, DC-optimized inverters, and premium panels), tract-level demographic controls (population density, owner-occupied housing density, median age, median income, percentage of population without a high school diploma, and percentage of population with a bachelor's degree), and fixed effects for installers, financiers, counties, and quote months. The customer payment regressions also include contract variables (escalation rate, down payment, and term) interacted with the PPA indicator variable, and interactions between the fixed effects and the PPA indicator variable. 